九州大学学術情報リポジトリ

Kyushu University Institutional Repository

\title{
Mulching Effects and the Soil Organic Matter Dynamics in Crushed Bamboo Utilization at the Farmland
}

Omoto, Shojiro

Laboratory of Irrigation and Water Management, Division of Bioproduction of Environment Sciences, Department of Agro-environmental Sciences, Graduate School of Bioresource and Bioenvironmental Science

\section{Marui, Atsushi}

Laboratory of Irrigation and Water Management, Division of Bioproduction of Environment Sciences, Department of Agro-environmental Sciences, Graduate School of Bioresource and Bioenvironmental Science

Shinogi, Yoshiyuki

Laboratory of Irrigation and Water Management, Division of Bioproduction of Environment Sciences, Department of Agro-environmental Sciences, Graduate School of Bioresource and Bioenvi ronmental Science

https://doi.org/10.5109/20334

出版情報 : 九州大学大学院農学研究院紀要. 56 (2)，pp. 373-377，2011-09. 九州大学大学院農学研究院 バージョン：

権利関係: 


\title{
Mulching Effects and the Soil Organic Matter Dynamics in Crushed Bamboo Utilization at the Farmland
}

\section{Shojiro OMOTO ${ }^{1}$, Atsushi MARUI* and Yoshiyuki SHINOGI}

\author{
Laboratory of Irrigation and Water Management, Division of Bioproduction of Environment \\ Sciences, Department of Agro-environmental Sciences, Faculty of Agriculture, \\ Kyushu University, Fukuoka 812-8581, Japan \\ (Received May 6, 2011 and accepted May 9, 2011)
}

\begin{abstract}
The objective of this research was to evaluate the effect of covering the soil surface with the crushed bamboo and to simulate the soil organic matter dynamics after the crushed bamboo was put into the soil at farmland. The first experiments in the phytotron $\left(25^{\circ} \mathrm{C}, 70 \%\right)$ showed that covering the soil with the $2 \mathrm{~cm}$ and $4 \mathrm{~cm}$ thick crushed bamboo prevented the decrease of the soil water content as well as vinyl mulching, and reduced the total amount of the irrigated water $20 \%$ less than no mulching. In addition, the crushed bamboo mulching kept the soil temperature lower than the others and made the electrical conductivity in the soil high just after irrigation. The second experiment showed that the crushed bamboo mulching applied the potassium to the crown daises so that the potassium content of the crown daises increased. Finally, the soil organic matter dynamics was simulated with the CENTURY model. It was predicted that if the $2 \mathrm{~cm}$ thick crushed bamboo was put into the soil, the most was decomposed in 20 years, and when it was put into the soil every year, the total amount of the soil organic carbon increased $7000 \mathrm{~g} / \mathrm{m}^{2}$ in 20 years, which made the $\mathrm{C}$ : $\mathrm{N}$ ratio keep 20. In this simulation, it seemed that the crushed bamboo of which thickness was less than $2 \mathrm{~cm}$ can be applied.
\end{abstract}

\section{INTRODUCTION}

Since 1960, the development of the chemical products and the aging of farm hands have led to the increase of the desolate bamboo grove which have caused the bamboo invasion to the farm and the simplification in the forest ecosystem in the western Japan. As one of the methods that solve such problems, the crushed bamboo that made by mashing the bamboo with high pressure and dried has been used to cover the soil surface as the mulching stuff and put into the soil after cultivation. However, Makishima (2009) reported that when the soil surface was covered with $15 \mathrm{~cm}$ thick crushed bamboo, the electric conductivity (EC) value of saturation water showed $3.3 \mathrm{mS} / \mathrm{cm}$ because of potassium ion. On the other hands, Yamakawa et al. (2009a) reported that the crushed bamboo mulching increased the harvest and the potassium emitting from the crushed bamboo cause the good effect to the crops on soybeans cultivation. And Yamakawa et al. (2009b) reported that the crushed bamboo mulching increased the seed yield more than mixing the soil with the crushed bamboo. It was because the inorganic nitrogen changed to the organic matter. It was necessary for promoting the use of the crushed bamboo to evaluate the effect of covering the soil surface with the crushed bamboo and to inspect the safety of putting it into the soil.

In order to estimate soil organic dynamics after the crushed bamboo was put into the soil, it was necessary that the model could simulate in a long term at a farm-

1 Laboratory of Irrigation and Water Management, Division of Bioproduction of Environment Sciences, Department of Agroenvironmental Sciences, Graduate School of Bioresource and Bioenvironmental Science

* Corresponding author (E-mail: marui.atsushi.281@m.kyushu-u. ac.jp) land. The CENTURY model is one of the some useful dynamics models of soil organic carbon in the world. Especially, the CENTURY model can simulate Carbon, Nitrogen, Phosphorus and Sulfur dynamics. And it is a site-specific model based on simplified soil-plant-climate interactions (Smith et al., 2009). The model evaluates agricultural management practices such as seeding, tillage, grazing, organic matter addition, and fertilizer application. Through a plant production submodel, Century simulates aboveground and belowground biomass production of crops, grasslands, forests, or savanna. A soil organic matter submodel predicts changes in levels of soil organic carbon based on microbe decomposed plant residues and resulting microbial products are the substrate for humus formation. The extent to which the decomposed compounds are stabilized is a function of soil texture (Parton et al., 1988). Oelbermann (2010) reported that the CENTURY model accurately evaluated the levels of SOC on a tropical and temperate alley crop.

In this research, the pot cultivation experiments were conducted to evaluate the effect of covering the soil surface with the crushed bamboo such as water consumption and fertilizer effects. And the simulation of the soil organic matter dynamics by the CENTURY model were also conducted to predict the long term dynamics of soil organic matter after the crushed bamboo was put into the soil at farmland.

\section{MATERIALS AND METHODS}

\section{Pot cultivation experiment}

Ex1. The effect to the soil water content, temperature, EC by covering with the crushed bamboo

A pot cultivation experiment was conducted for 85 days to evaluate the saving water effect of covering the soil surface with the crushed bamboo. The soybeans 
(Glycine max) were cultivated in the 1/5000 a wagner pots at the phytotron where temperature and humidity were constant $\left(25^{\circ} \mathrm{C}, 70 \%\right)$. There were four treatments (control, vinyl mulch, $2 \mathrm{~cm}$ mulch, $4 \mathrm{~cm}$ mulch) and two pots for each treatment. In brief, the treatments were: 'control' covered the soil surface with nothing, 'vinyl mulch' covered the soil surface with a black vinyl, ' $2 \mathrm{~cm}$ mulch' and ' $4 \mathrm{~cm}$ mulch' covered the soil surface with $2 \mathrm{~cm}$ and $4 \mathrm{~cm}$ thick crushed bamboo which weighed $65 \mathrm{~g}$ and $130 \mathrm{~g}$, respectively. The soil was decomposed granite soil that was passed through a $2 \mathrm{~mm}$ sieve. The soil water content, temperature and electrical conductivity (EC) were measured by TDR $\left(\mathrm{ECH}_{2} \mathrm{O}-\mathrm{TE}\right)$ which was set at $6 \mathrm{~cm}$ depth from the soil surface. Irrigation condition was that when the soil water content reduced to 14\%, $224 \mathrm{ml}$ distilled water was irrigated with sprinkling can. The fertilizer (N: P: K = $600 \mathrm{~g}: 1000 \mathrm{~g}: 1000 \mathrm{~g}$ ) was applied as a base manure.

Ex2. The effect of potassium fertilizing by covering with the crushed bamboo

A pot cultivation experiment was conducted for 40 days to evaluate fertilizing effect of covering the soil surface with crushed bamboo. Crown daisies (Glebionis coonaria (L.)) after 5 days from germinating were cultivated in the 1/5000 a wagner pots in a green house at Kaiduka farm. There were four treatments (control, $2 \mathrm{~cm}$ mulch, liquid 1, liquid 2) and two types of fertilization (N: P: K = 800 g: 800 g: 800 g, N: P: K = 800 g: 800 g: $400 \mathrm{~g}$ ) for each treatment. In brief, the treatments were: 'control' was that the soil surface was covered with nothing and distilled water was irrigated, ' $2 \mathrm{~cm}$ mulch' was that the soil surface was covered with $2 \mathrm{~cm}$ thick crushed bamboo and distilled water was irrigated, 'liquid 1' and 'liquid 2' meant that the both soil surfaces were covered with nothing and the filtrate which passed through $65 \mathrm{~g}$, $130 \mathrm{~g}$ crushed bamboo (Fig. 1) was irrigated, respectively. Table1 showed the ingredient of the filtrate which potassium ion density was so high that the previous study proved. The soil was decomposed granite soil that was passed through a $2 \mathrm{~mm}$ sieve. Irrigation condition

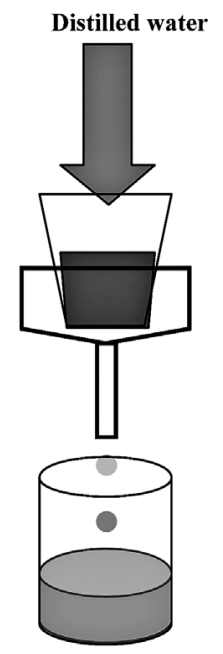

Fig. 1. Schematic view of Filtrate passed through the crushed bamboo.
Table 1. Ingredient of the filtrate passed through the crushed bamboo

\begin{tabular}{lccrrr}
\hline & & first & second & third & fourth \\
\hline liquid 1 & $\begin{array}{c}\text { EC (mS/cm) } \\
\text { potassium ion } \\
\text { density (mg/L) }\end{array}$ & 0.002 & 0.351 & 1.195 & 0.246 \\
\hline liquid 2 & $\begin{array}{c}\text { EC (mS/cm) } \\
\text { potassium ion } \\
\text { density (mg/L) }\end{array}$ & 0.002 & 0.465 & 1.372 & 0.759 \\
\hline
\end{tabular}

was that the soil was kept wet for 20 days, and then $200 \mathrm{ml}$ distilled water or filtrate was irrigated once every eight days. Irrigation was conducted at the same time in each pot not to make the difference of growth. Dry mass and potassium content were measured after cultivation.

\section{Simulation. Prospecting the soil organic matter dynamics}

The decomposed rate of crushed bamboo in the soil was calculated, and the long-term soil organic matter dynamics was predicted on soybeans cultivation between 1977 and 2077 with the CENTURY model. The specific site was soybeans farm in Itoshima city, western of Fukuoka prefecture. There were five cases in this simulation: case1 was that the crushed bamboo was not put, case 2 was that the crushed bamboo was put only for first year to calculate the decomposed rate of the crushed bamboo which weight was $3250 \mathrm{~g} / \mathrm{m}^{2}$ ( $2 \mathrm{~cm}$ thick), on the other hand, case3, case4, case5 were that the crushed bamboo was put every year and its weight was $1625 \mathrm{~g} / \mathrm{m}^{2}$ ( $1 \mathrm{~cm}$ thick), $3250 \mathrm{~g} / \mathrm{m}^{2}$ ( $2 \mathrm{~cm}$ thick), $6500 \mathrm{~g} / \mathrm{m}^{2}$ ( $4 \mathrm{~cm}$ thick), respectively (Table 2 ). The schedule of cultivating soybeans was determined by hearing from JA Itoshima and farmers (Table 3). Climate data was taken from Maebaru weather observatory between 1977 and 2009 (Table 4). The soil texture data was that the sand,

Table 2. Case of crushed bamboo application in the simulation

\begin{tabular}{cccc}
\hline \multirow{2}{*}{ case } & \multicolumn{2}{c}{ crushed bamboo $\left(\mathrm{g} / \mathrm{m}^{2}\right)$} & means of application \\
\cline { 2 - 3 } & thickness & mass $\left(\mathrm{g} / \mathrm{m}^{2}\right)$ & \\
\hline 1 & - & 0 & - \\
2 & $2 \mathrm{~cm}$ & 3250 & only first year \\
3 & $1 \mathrm{~cm}$ & 1625 & every year \\
4 & $2 \mathrm{~cm}$ & 3250 & every year \\
5 & $4 \mathrm{~cm}$ & 6500 & every year \\
\hline
\end{tabular}

Table 3. Soybeans cultivation schedule

\begin{tabular}{cc}
\hline & soybeans management \\
\hline June & Cultivation \\
July & start to grow \\
& fertilizer $\left(\mathrm{N}: 2 \mathrm{~g} / \mathrm{m}^{2}\right)$ application \\
& crushed bamboo application \\
August & middle cultivation \\
September & middle cultivation \\
November & harvest \\
\hline
\end{tabular}


Table 4. Climate data at Maebaru weather station from 1977 to 2009

\begin{tabular}{cccccc}
\hline & $\begin{array}{c}\text { Precipitation } \\
(\mathrm{cm} / \text { month) }\end{array}$ & $\begin{array}{c}\text { Standard Deviation } \\
\text { for Precipitation }\end{array}$ & $\begin{array}{c}\text { Skewness Value } \\
\text { for Preipitation }\end{array}$ & $\begin{array}{c}\text { Maximum } \\
\text { Temperature }\left({ }^{\circ} \mathrm{C}\right)\end{array}$ & $\begin{array}{c}\text { Minimum } \\
\text { Temperature }\left({ }^{\circ} \mathrm{C}\right)\end{array}$ \\
\hline January & 75.3 & 38.3 & 2.1 & 15.7 & -2.6 \\
February & 77.8 & 37.1 & 1.0 & 17.6 & -2.5 \\
March & 120.7 & 46.5 & 0.5 & 20.7 & -0.8 \\
April & 120.5 & 47.5 & 0.3 & 26.0 & 2.5 \\
May & 138.7 & 67.6 & 0.2 & 28.8 & 8.3 \\
June & 260.4 & 142.3 & 0.5 & 31.5 & 13.2 \\
July & 285.6 & 217.8 & 0.8 & 34.0 & 19.4 \\
August & 193.4 & 169.4 & 3.4 & 34.8 & 19.9 \\
September & 187.0 & 119.1 & 1.8 & 32.5 & 14.3 \\
October & 85.6 & 69.4 & 1.6 & 27.3 & 7.0 \\
November & 93.9 & 48.7 & 0.7 & 23.1 & 2.3 \\
December & 69.1 & 35.7 & 0.9 & 18.4 & -1.0 \\
\hline
\end{tabular}

silt, and clay content were $80 \%, 3 \%$ and $2 \%$, which was taken from the farm in Itoshima. C: $\mathrm{N}$ ratio of crushed bamboo was 85.09 and lignin content was obtained $29 \%$ by detergent analysis.

\section{RESULTS AND DISCUSSION}

\section{Pot cultivation experiment}

\section{Ex1. Saving water effect}

Fig. 2 shows the changes of the soil water content from August 13 to September 1. Covering the soil surface with the crushed bamboo prevented the decrease of the soil water content as well as black vinyl. However, the crushed bamboo absorbed the water that should be applied to the soil, so the soil water content didn't increase little in the irrigation. Compared with in 'con-
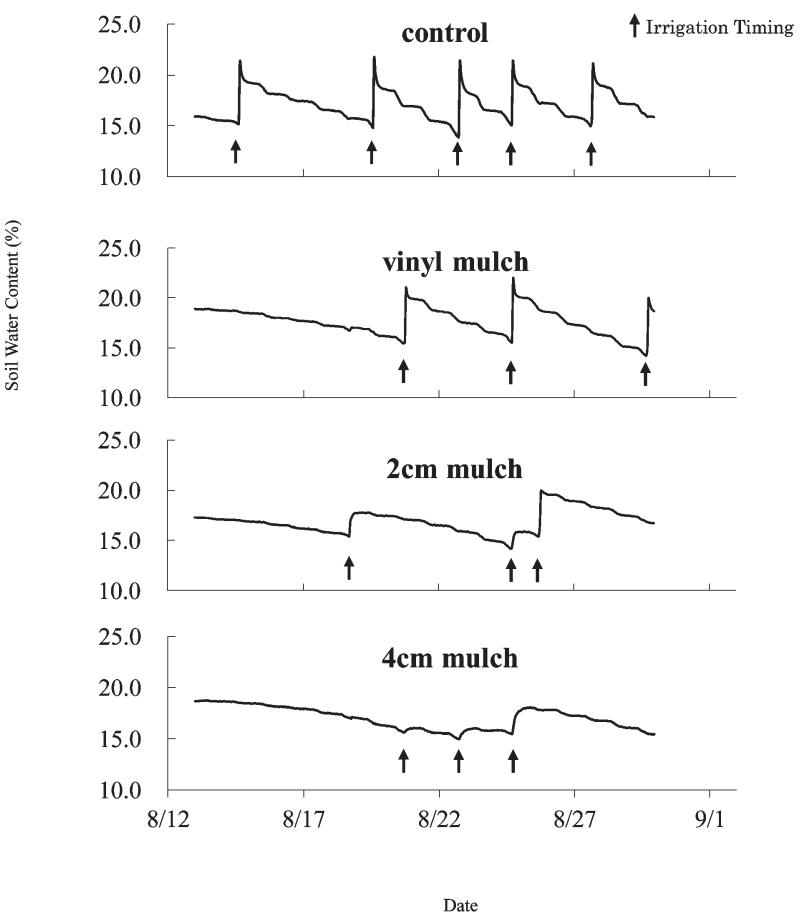

Fig. 2. Change of the soil water content in each pot. trol', the frequency of irrigation was reduced in both ' $2 \mathrm{~cm}$ mulch' and ' $4 \mathrm{~cm}$ mulch', and the total of irrigated water was decreased $20 \%$ off (Fig. 3). There were no significant differences between ' $2 \mathrm{~cm}$ mulch' and ' $4 \mathrm{~cm}$ mulch', so ' $2 \mathrm{~cm}$ mulch' was enough to prevent the decrease of the soil water content, and ' $4 \mathrm{~cm}$ mulch' seemed to absorb so much water. Fig. 4 shows the changes of the soil temperature. $2 \mathrm{~cm}$ mulch and $4 \mathrm{~cm}$ mulch made the soil temperature lower than the others. It seemed to be because that the crushed bamboo insulated the heat from sunshine. Fig. 5 shows the changes of EC just after irrigation. In the first period, EC value was a little high because of fertilizer. Especially, EC value

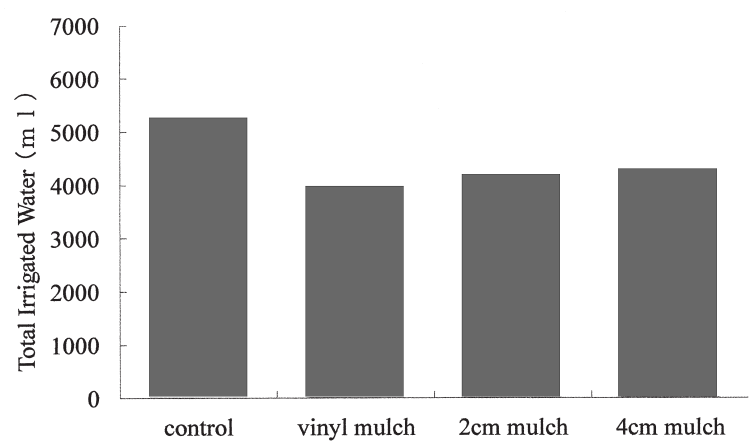

Fig. 3. Total amount of the irrigated water $(n=2)$.

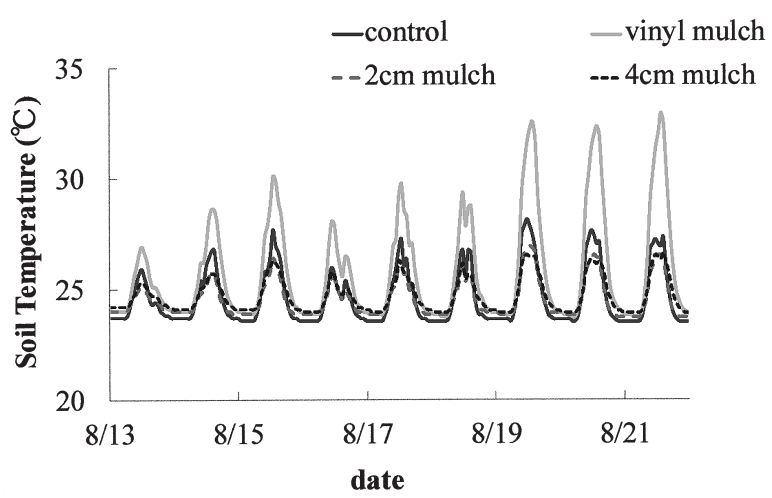

Fig. 4. Changes of the soil Temperature in each pot. 


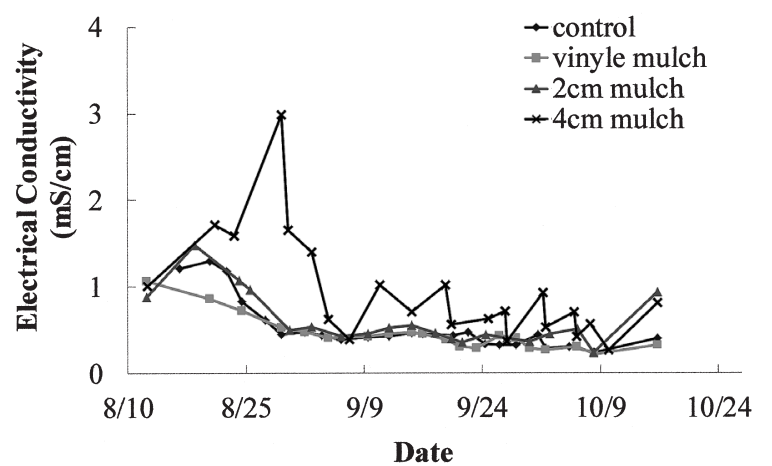

Fig. 5. Changes of the Electrical Conductivity in each pot just after irrigation.

of ' $4 \mathrm{~cm}$ mulch' showed about $3.0 \mathrm{mS} / \mathrm{cm}$. It seemed that the potassium was emitted from the crushed bamboo. So, it is necessary to concern about.

\section{Ex2. Fertilizing effect}

Fig. 6 shows the dry mass of crown daisies after the experiment. As 'control' was 100\%, '2 cm mulch', 'liquid 1 ' and 'liquid 2' were $70.5 \%, 94.5 \%$ and $132.9 \%$ in the fertilizer (K= $800 \mathrm{mg}$ ) and 55.5\%, 108.8\% and 130.7\% in the fertilizer ( $K=400 \mathrm{mg}$ ), respectively. Though the dry mass of 'liquid 2' showed the highest, that of ' $2 \mathrm{~cm}$ mulch' was the lowest. It seemed to be because it was too wet for the crown daisies to grow very well by saving water

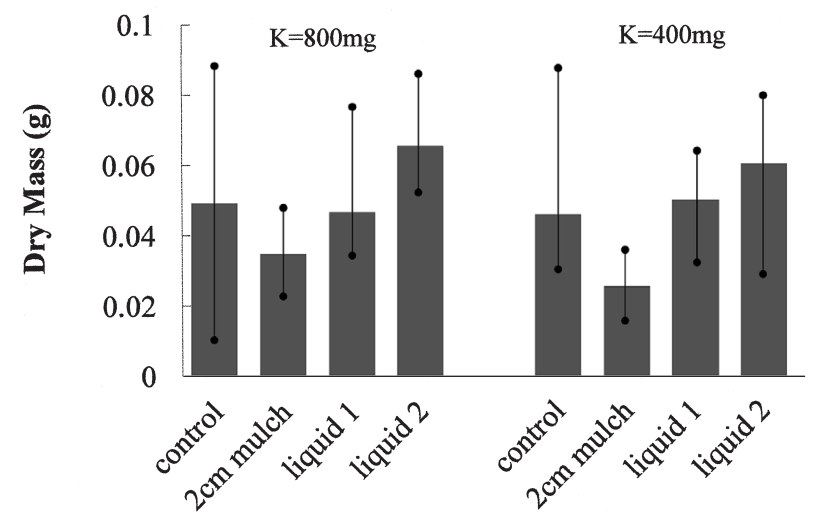

Fig. 6. Dry mass of crown daisies after pot cultivation experiment for fertilizer effect $(n=3)$.

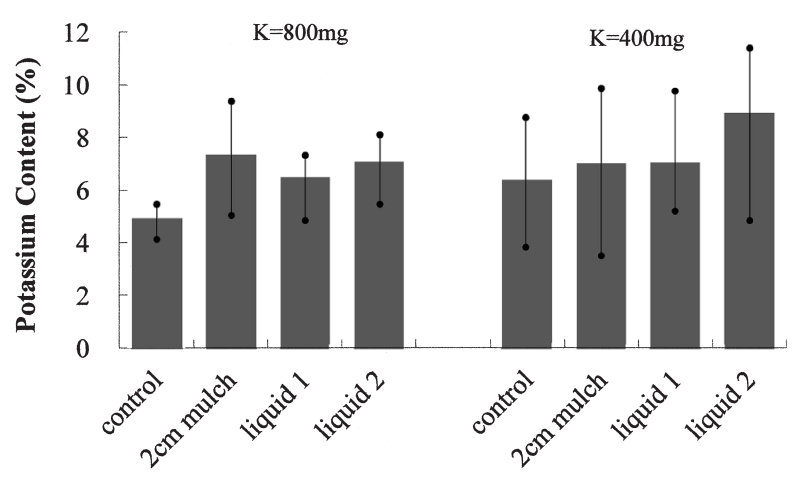

Fig. 7. Potassium Content of crown daisies after pot cultivation experiment for fertilizer effect $(n=3)$. effect of the crushed bamboo mulch. Fig. 7 showed the potassium content of crown daisies. As 'control' was 100\%, '2 cm mulch', 'liquid 1' and 'liquid 2' were 148.7\%, $131.2 \%$, and $109 \%$ in the fertilizer ( $\mathrm{K}=800 \mathrm{mg}$ ), and $109.6 \%, 110 \%$ and $139.7 \%$ in the fertilizer ( $K=400 \mathrm{mg}$ ), respectively. It was considered that potassium emitted from crushed bamboo was absorbed by the crops.

\section{Simulation. Prospecting the soil organic matter dynamics}

Fig. 8 shows the changes of the total of the Soil Organic Carbon (SOC) in the case1 and case2. The total SOC in the case 2 approached the case 1 in 20 years. The results showed that most of crushed bamboo was seem to be decomposed in 20 years. Fig. 9 showed the changes of the total SOC in the case1, case3, case 4 and case 5 . The case 3 , case 4 and cas5 was that the total SOC increased by about $4000 \mathrm{~g} \mathrm{C} / \mathrm{m}^{2}, 7000 \mathrm{~g} \mathrm{C} / \mathrm{m}^{2}, 14000 \mathrm{~g} \mathrm{C} / \mathrm{m}^{2}$, respectively. Increase of the $\mathrm{SOC}$ leads to the rise of $\mathrm{C}$ : $\mathrm{N}$ ratio. If $\mathrm{C}$ : $\mathrm{N}$ ratio in the soil went up over 20 , there was the possibility of nitrogen starvation, the soil microbe intercepts nitrogen that crops should absorb. So C: $\mathrm{N}$ ratio in the soil calculated (Fig. 10). In the case3, C: N ratio didn't get over 20. But it remained nearly 20 in the case 4 and it exceeded 20 in the case 5 . In the case 4 , it was concerned that nitrogen starvation occurred, so cultivation was added in December on the schedule (Fig. 11). It

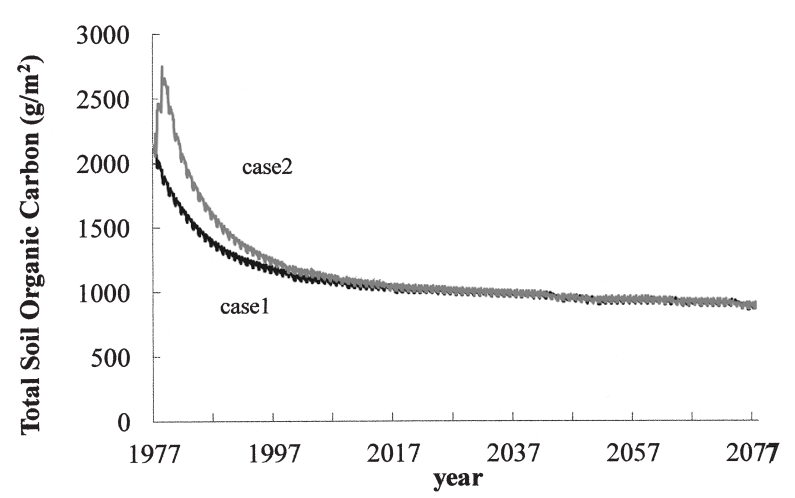

Fig. 8. Changes of total amount of the Soil Organic Carbon of case 1 and case2.

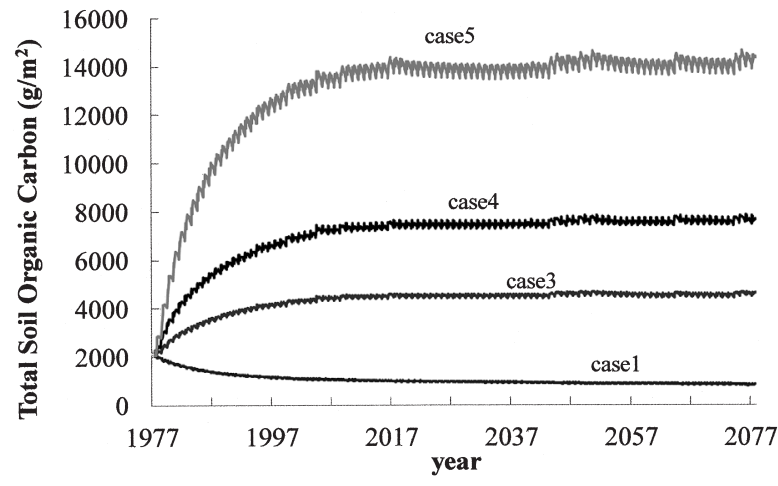

Fig. 9. Changes of total amount of the Soil Organic Carbon of case 1 , case3, case 4 and case 5 . 


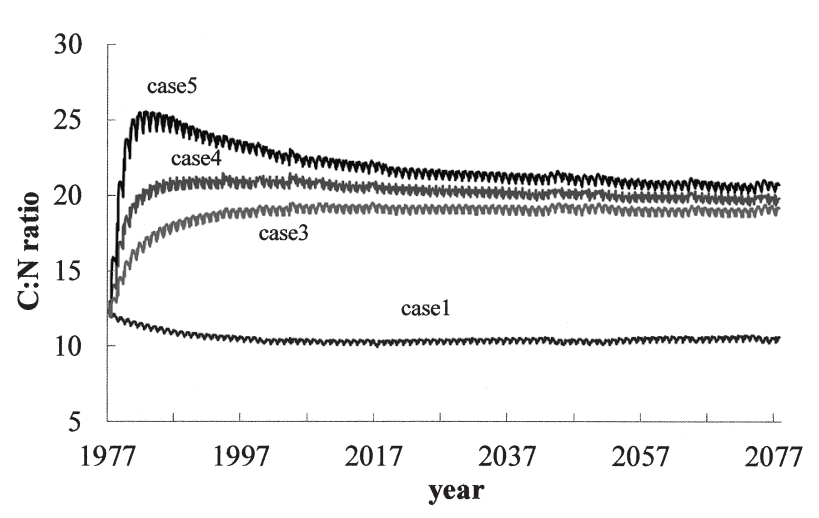

Fig. 10. Changes of C: $N$ ratio of case1, case3, case 4 and case5.

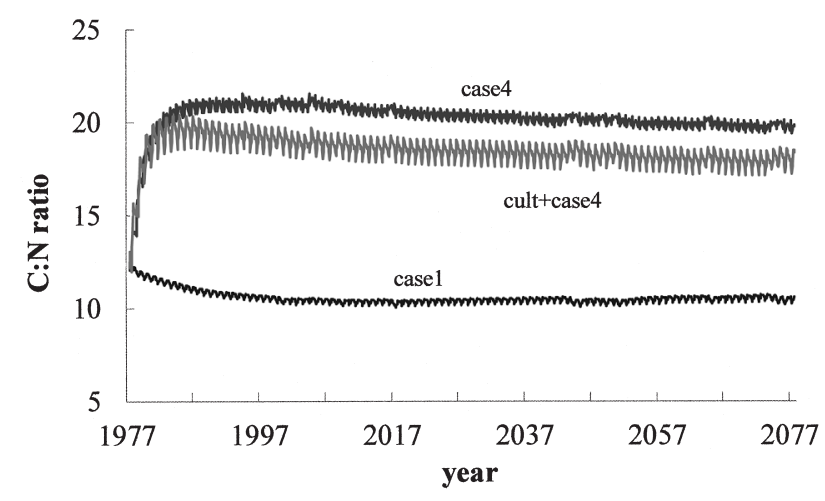

Fig. 11. Changes of $C: N$ ratio of case 1 , case 4 and cult+case 4 .

made $\mathrm{C}$ : $\mathrm{N}$ ratio decrease and removed the concern of nitrogen starvation. In this simulation, it seemed that the crushed bamboo of which thickness was less than $2 \mathrm{~cm}$ can be applied.

\section{CONCLUSION}

Pot cultivation experiments were conducted to evaluate the effect of the crushed bamboo mulch. In addition, the CENTURY model simulated the soil organic matter dynamics after crushed bamboo had been put into the soil.

Covering the soil surface with the crushed bamboo prevented the decrease of the soil water content, and the total of irrigated water was reduced $20 \%$ less than no mulching. But there was no significant difference between $2 \mathrm{~cm}$ and $4 \mathrm{~cm}$ thick crushed bamboo mulching. As regards saving water, $2 \mathrm{~cm}$ thick crushed bamboo mulching gives enough effect. It was necessary to con- cern that the crushed bamboo mulching insulated the heat from sunshine and EC in the soil showed about $3.0 \mathrm{mS} / \mathrm{cm}$ just after irrigation.

The filtrate which was passed through $130 \mathrm{~g}$ crushed bamboo increased the dry mass of the crown daises, but the $2 \mathrm{~cm}$ thick crushed bamboo mulching kept the soil too wet for the crown daises and its dry mass decreased. The potassium content of the crown daises increased because of the application of crushed bamboo mulching and the filtrate of the crushed bamboo.

The CENTURY model simulated that most of crushed bamboo was decomposed in 20 years and the soil organic carbon increased $7000 \mathrm{~g} \mathrm{C} / \mathrm{m}^{2}$ when $2 \mathrm{~cm}$ thick crushed bamboo was applied every year, which made C: $\mathrm{N}$ ratio keep 20. In this simulation, it seemed that the crushed bamboo of which thickness was less than $2 \mathrm{~cm}$ can be applied.

\section{ACKNOWLEDGEMENT}

This research was partially supported by the Grantin-Aid for Young Scientists (B), (Grant number: 21780226), Ministry of Education, Culture, Sports, Science and Technology, Japan (MEXT Grant).

\section{REFERENCES}

Makishima, K. and A. Marui 2009 Effect on the water quality in farmland covering soil surface by an organic matter. Proc. of the 90th technical meeting of Kyushu Branch of the Japanese Society of Irrigation, Drainage and Rural Engineering, 20-21 (in Japanese)

Nishio, M. 2007 Basic Knowledge of Compost and Organic Fertilizer Rural Culture Association Press, (JAPAN) (in Japanese)

Oelbermann, M. and R. P. Voroney 2010 An evaluation of the century model to predict soil organic carbon: examples from Costa Rica and Canada. Springer Science+Business Meia B. V. 2010

Shirato, Y. 2006 Validation and Modification of Soil Organic Matter Models in Arable Soils in Japan and Thailand. NIAES Report, 24: 92-42 (in Japanese)

Smith, W. N., B. B. Grant, R. L. Desjardins, B. Quian, J. Hutchinson and S. Gameda 2009 Potential impact of climate change on carbon in agricultural soils in Canada. Climatic Change, 93: 319-333

Parton, W. J., J. W. B. Steweart and C. V. Cole 1998 Dynamics of C, N, P and S in grassland soils: a model. Biochen, 5: 109-131

Yamakawa, T., M.Yamano and M. Ikeda 2009a Effect of applying $\mathrm{K}$ and mulching with crushed bamboo on the growth and yield of soybean (Glycine $\max$ L. Merr.) 'Fukuyutaka'. Journal of the science of soil and manure, 80: 7-13 (in Japanese)

Yamakawa, T., M. Yamano and M. Ikeda 2009b Effect of applied position of crushed fibrous-banboo and nitrogen fertilizer on yield and N, P, K accumulation of soybean (Glycine max L. Merr.) cv.Fukuyutaka. Journal of the science of soil and manure, 80: 379-386 (in Japanese) 